\title{
On-Premise Signs and the North American Suburban Enclosed Shopping Mall
}

\section{Craig Berger}

Liaison for Development and Curricular Support

CD Pathways

Fashion Institute of Technology

craig_berger@fitnyc.edu

THE FIVE STAGES OF SUBURBAN ENCLOSED

\section{MALL DEVELOPMENT}

Stage 1: 1950-1970

Egalitarian Shopping Center

\section{Economic Trend:}

- $\quad$ Rise of the middle class

- Expansion of department stores as a primary outlet for retail

- Suburban auto oriented growth

\section{Design Trend:}

- $\quad$ European modernism

- Introduction of Environmental Graphics

- Interior malls anchored by department stores

Sign Trend:

- Illuminated channel Letter signs

- Monument signs

The years immediately following World War II were a time of rapid income growth resulting in a massive increase in discretionary spending. The widespread ability to purchase homes and cars prompted a push towards suburban development for the white working and middle class. The suburban population doubled from 37 to 74 million from 1950-1970 (Jackson, 1985). City department stores were forced to turn to suburban markets for their future survival. These stores tried to create urban-level shopping density in an automobile-oriented environment. The enclosed shopping mall congregated multiple department stores and specialty stores in one location
Abstract /

The first fully enclosed modern suburban shopping mall, Southdale Center, opened in 1956 and immediately established a standard for how retailers and signs were to operate within their confines. Enclosed Malls were one of the first unique building types designed for suburban automotive environments and have been a key retail economic driver in the United States for seventy years. The mall also reflected economic changes in the country and the increasing separation of income classes. Malls established a variety of sign innovations over the years, from developing strict sign guidelines, to creating formal zones with shared modular systems. This report will explore the sign advances that marked each of the five stages of mall evolution impacted design and development. The report will also show how precedents established early in the history of mall development as a center for a broad range of incomes changed as malls began to segment by class.

\section{Keywords /}

shopping malls, enclosed mall, suburban automotive environments, key retail economic driver, separation of income classes, sign innovations, sign guidelines, shared modular systems, five stages, broad range of incomes, segment, class. 
to create the shopping volumes needed.

Malls were among the first suburban buildings designed by architects who were heavily influenced by both European enclosed shopping boulevards developed in the late 19th century and modern postwar architecture. The result was mall buildings focused on a few key entrance gateways, built around department stores, and featuring long multi-floor interior arcades. Early malls were developed to reach a broad range of consumers with a variety of store types. (Frieden \& Sagalyn, 1989)

As architecture firms developed suburban retail buildings, they imposed greater control over retail sign rules and guidelines, motivated by the need comply with modern design values. This design approach resulted in the integration of environmental graphics to develop an overall identity for the mall and in tight covenants for retail signs. Illuminated channel letter signs became the key medium of expression. They allowed for some flexibility in type styles while forcing consistency in color, size and materials.

The Northland Mall (see Figure 1) was designed by mall pioneer Victor Gruen and was one of the first major enclosed centers in the country. It had a number of innovations including anchor department stores and enclosed atrium spaces meant to mirror European shopping boulevards. This mall was also a pioneer for sign development. Gruen hired Alvin Lustig, one of the most famous graphic designers of the 20th century, to develop a monument sign, landmark signs and wayfinding for the mall. Northland Mall had rigid rules for sign development focused on illuminated channel letter, a style that supported the clean lines and minimalist architecture of the building. Northland was converted from an exterior mall and still had a mix of interior and exterior signs when it opened. Later restrictions would allow only department stores and supermarkets to have exterior signs (Dugdale, 1999).

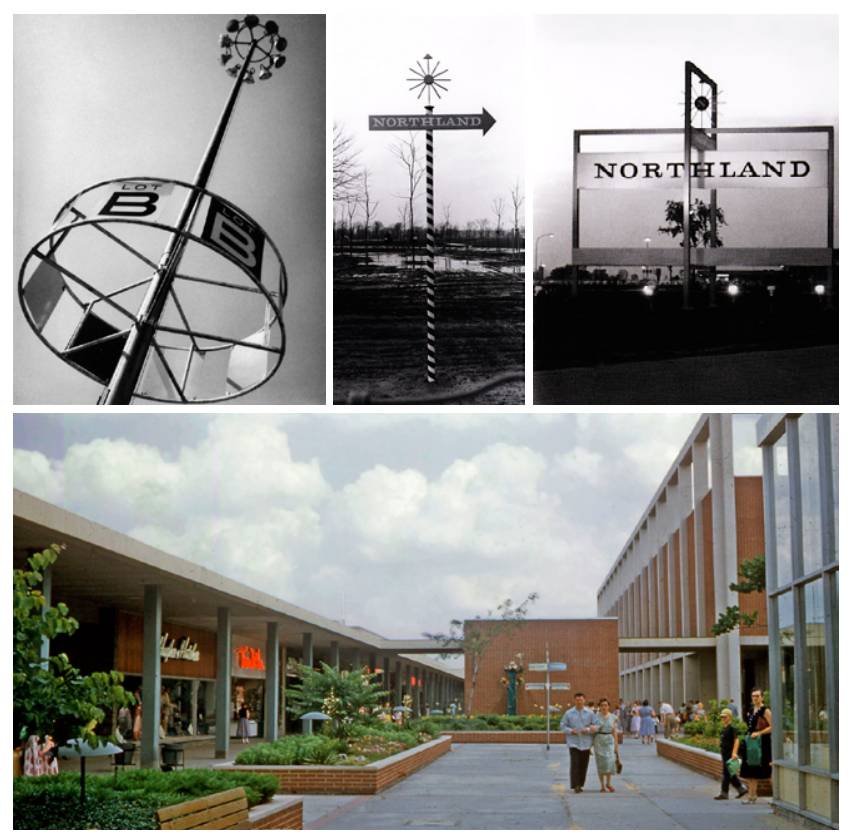

Figure 1 / Northland Mall Photo / Elaine Cohen Lustig

Photo / Gruen Associates 
Stage $2: 1970-1985$

Segmentation of the Market

\section{Economic Trend:}

- $\quad$ Land segmentation by income

- Income inequality

- $\quad$ Luxury brands

\section{Design Trend:}

- Postmodernism

- $\quad$ Food courts

- $\quad \mathrm{A}, \mathrm{B}$, and C Malls

\section{Sign Trend:}

- $\quad$ Differentiated stores and display

- Modular systems

- Higher material investment

As the suburbs grew, they became home to members of income groups from the lower middle class to the wealthy. These groups have different tastes that do not always match. Luxury product brands began to look at suburban malls as way to raise their profiles beyond urban anchor stores and department stores (Underhill, 2004).

Mall developers and real estate analysts began segmenting malls to reach specific income groups. Malls were designated A, B, C and D to differentiate how many dollars per square foot they would generate (see Figure 2). "A" malls attract luxury brands and require more attention to store display and presentation. In this second stage, malls needed to provide more attractive environments and more ornate design approaches than the modern architectural trends of the earlier era (Stage 1) could support.

\begin{tabular}{|c|c|c|c|}
\hline \multicolumn{4}{|c|}{$\begin{array}{c}\text { REGIONAL MALL CLASSIFICATION CONCLUSIONS } \\
\text { In-line Retail Sales Per Square Foot }\end{array}$} \\
\hline $\begin{array}{c}\text { Mall } \\
\text { Classification }\end{array}$ & As of $1 / 1 / 13$ & As of $1 / 1 / 14$ & As of $1 / 1 / 15$ \\
\hline Trophy & -- & $\$ 800$ & $\$ 800$ and up \\
\hline $\mathrm{A}^{+}$ & $\$ 625$ and up & $\$ 650$ and up & $\$ 650$ and up \\
\hline A & $\$ 475$ to $\$ 624$ & $\$ 500$ to $\$ 649$ & $\$ 500$ to $\$ 649$ \\
\hline $\mathrm{B}^{+}$ & $\$ 400$ to $\$ 474$ & $\$ 425$ to $\$ 499$ & $\$ 425$ to $\$ 499$ \\
\hline B & $\$ 325$ to $\$ 399$ & $\$ 325$ to $\$ 424$ & $\$ 325$ to $\$ 424$ \\
\hline $\mathrm{C}^{+}$ & $\$ 275$ to $\$ 324$ & $\$ 275$ to $\$ 324$ & $\$ 275$ to $\$ 324$ \\
\hline $\mathrm{C}$ & $\$ 250$ to $\$ 274$ & $\$ 250$ to $\$ 274$ & $\$ 250$ to $\$ 274$ \\
\hline$D$ & Less than $\$ 250$ & Less than $\$ 250$ & Less than $\$ 250$ \\
\hline \multicolumn{4}{|c|}{$\begin{array}{l}\text { Retail sales are for reporting inline tenants that were in occupancy for an entire year on a rolling } 12 \\
\text { month basis divided by the GLA for those tenants. Inline mall stores include stores less than } 10,000 \\
\text { square feet (including restaurants), but excludes temporary tenants and restaurants over } 10,000 \text { squar } \\
\text { feet and excludes Apple stores. }\end{array}$} \\
\hline \multicolumn{4}{|c|}{ Source: Korpacz Realty Advisors, Inc. survey was conducted by Peter F. Korpacz, MA, CRE, FRICS } \\
\hline
\end{tabular}

Figure 2 / Mall Classifications (Korpacz, 2017) Chart Credit / Korpacz Realty Advisors 
Figure 3 / South Coast Plaza

Photo / South Coast Plaza

Credit / Nandaro
The upgraded requirements of "A" malls extend to signs. The advent of the luxury mall allowed for much greater difference in store design, from thematic displays to customized signs and façades. Malls also began to invest more heavily in material details including architectural gateways and modular wayfinding solutions.

South Coast Plaza (see Figure 3) in Orange County, California, was built in 1967 and evolved into one of the largest luxury malls in the country. Stores in this mall are allowed greater branding opportunities. Considerable investment is made in common area signage and identity elements. To this day, this mall has remained profitable.
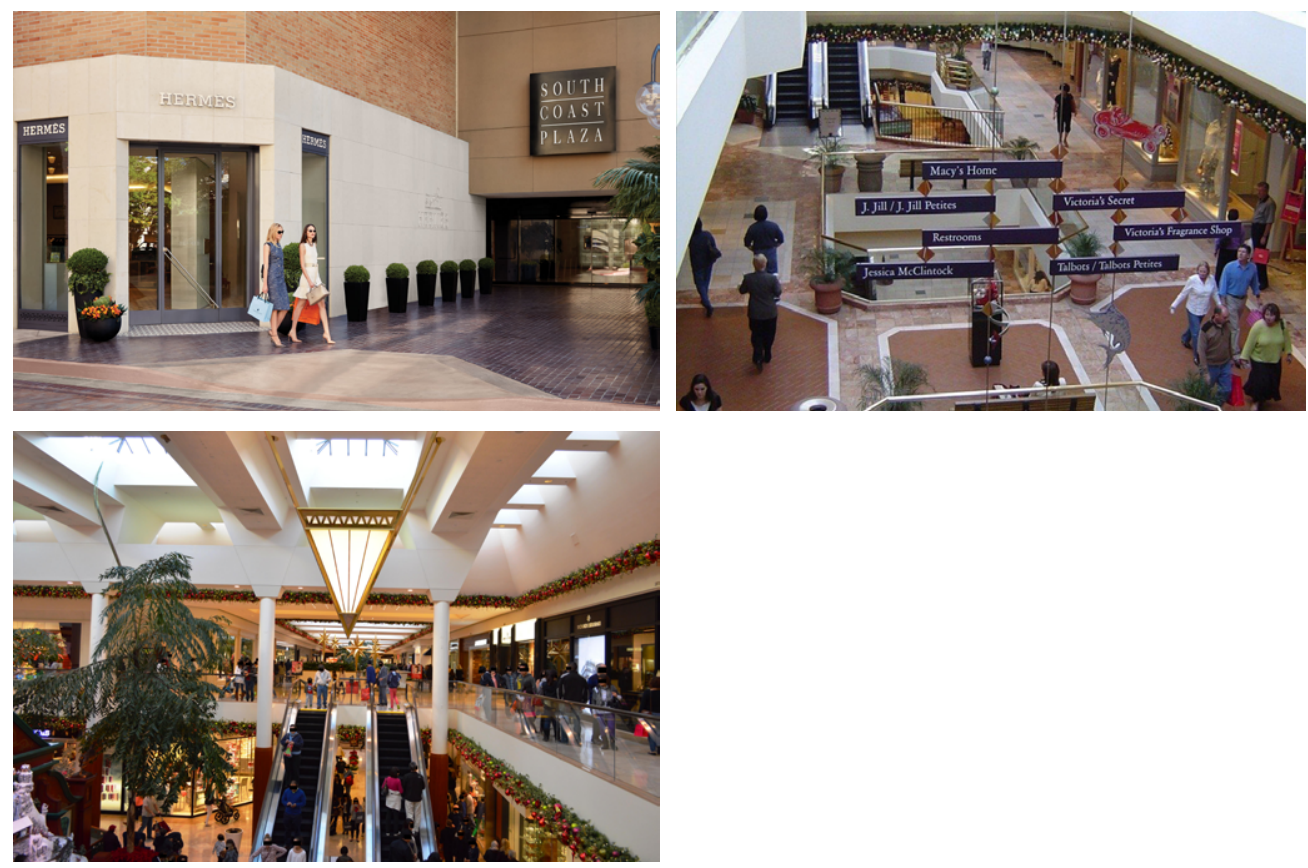

Stage 3 : $1985-2000$

National Malls and Regional Malls

Economic Trend:

- International travel

- Downtown revitalization

- Decline of small regional malls

- $\quad$ Competition from different

retail centers

- $\quad$ Themed restaurants and entertainment

Design Trend:

- $\quad$ Superstructures

- $\quad$ Themed environments

Sign Trend:

Themed signs and displays 
Figure 4 / Mall of America

Photo / Jeremy Noble

Photo Credit / Runner 1928
As a response to declining retail traffic, cities began to develop large thematic malls to attract more downtown visitors, starting with Fanueil Hall in Boston in 1976. The success of the "festival marketplace" coupled with a decline in business for smaller regional malls pushed developers to create very large themed environments that would combine shopping with entertainment (Judd \& Fainstein, 1999).

The design of these environments combined enclosed large superstructures with vibrant thematic graphics and displays. Retailers were encouraged to be as creative as possible and specialty restaurants were integrated with retail spaces.

Regional malls further segmented during this era. Successful malls underwent major renovations that pushed entertainment and retail creativity at a smaller scale. Smaller malls originally designed to serve as community centers began to decline as other community retail spaces like power centers and main street centers were introduced and promoted. Department stores also began to decline as discount retailers like Walmart and Target moved aggressively into the suburbs.

The Mall of America (see Figure 4) in Bloomington, Minnesota, was created to combine retail development and themed entertainment. Located across from an airport and designed to attract international visitors, the mall encourages retailers to develop themed environments as a way of promoting and expanding retail tourism. The mall has become a center for major media events including some 2018 Super Bowl activities.
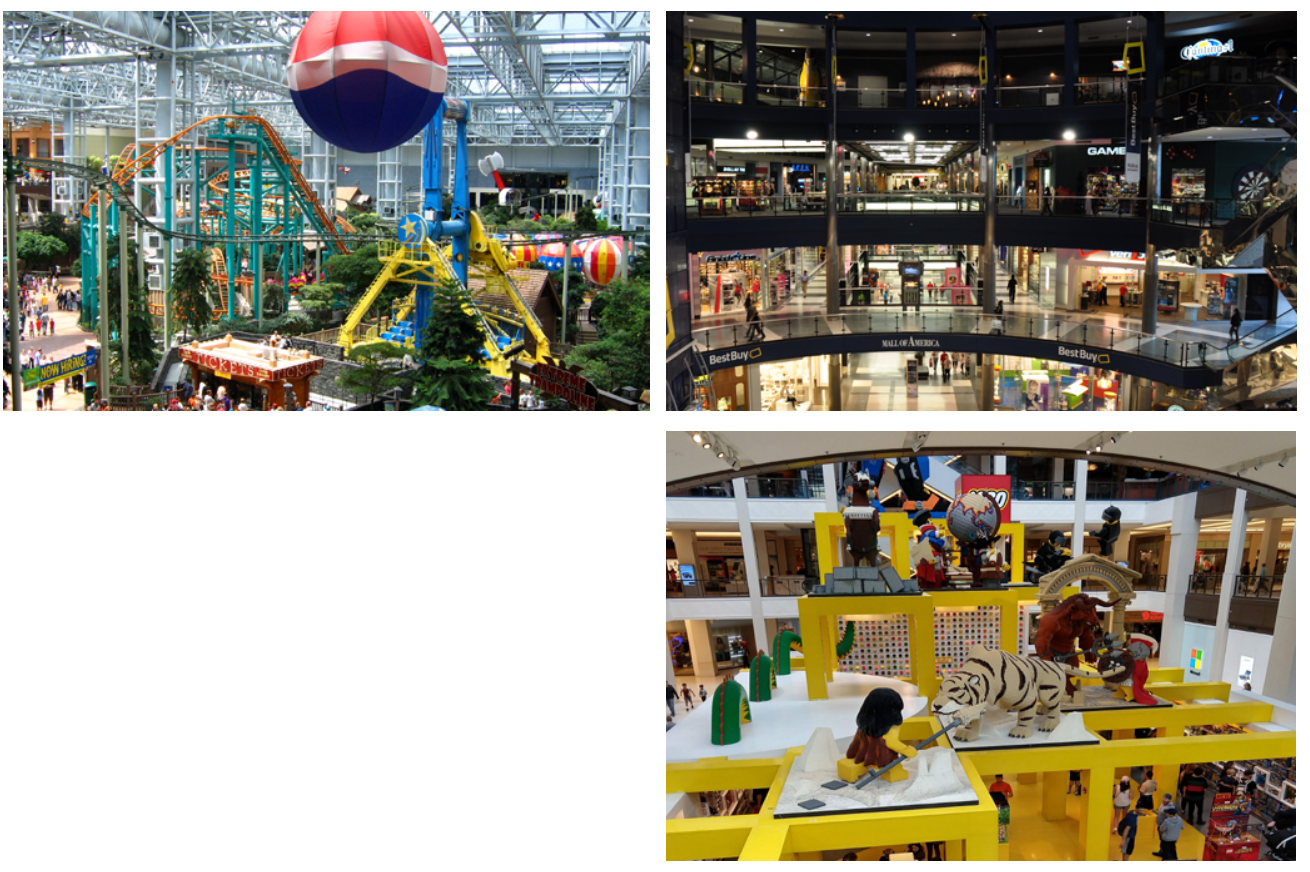
Stage $4: 2000$ - 2010

Renovation and Readjustment

\section{Economic Trend:}

- $\quad$ No new growth

- Decline of department stores as anchor properties

- $\quad$ Alternative uses

Design Trend:

- Renovation

- Architectural diversity

- $\quad$ Public spaces

\section{Sign Trend:}
- $\quad$ Branded structures
- Exterior illumination
- Interior/exterior signs

New enclosed mall construction essentially stopped in 2000 after 50 years of continual growth. Department stores, the key mall anchor, declined and then consolidated or closed. Retail space in the United States became oversaturated. Consumers came to regard malls as an experience instead of a convenience. Large mall developers responded by investing more heavily in more profitable "A" malls. This approach resulted in a small number of malls receiving a disproportionate amount of money for new development while a larger percentage of malls declined (Moore, 2013).

Interestingly the number of "A" malls as a percentage of all malls in 2015 was $20 \%$. This number matches the number of Americans considered upper income (see Figure 5) in 2015 (Pew Research Center, 2015). This correlation also extends to the increase in luxury malls between 1970 and 2015.

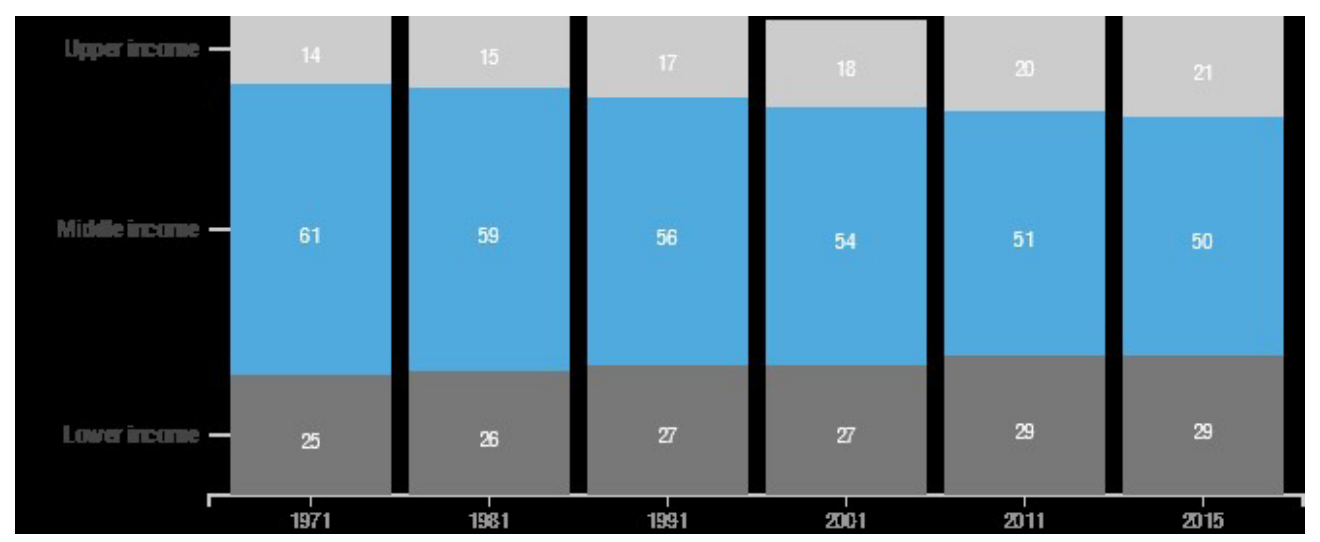

Figure 5 / Percentage of the US population in the upper, middle, and lower income levels in 2015

Advanced mall renovations focused on creating more exciting experiences that would mimic the best of revitalized cities, including architectural diversity and public space. Malls began to create more exciting and interesting façades and to combine the mall with public parks and residential facilities. 

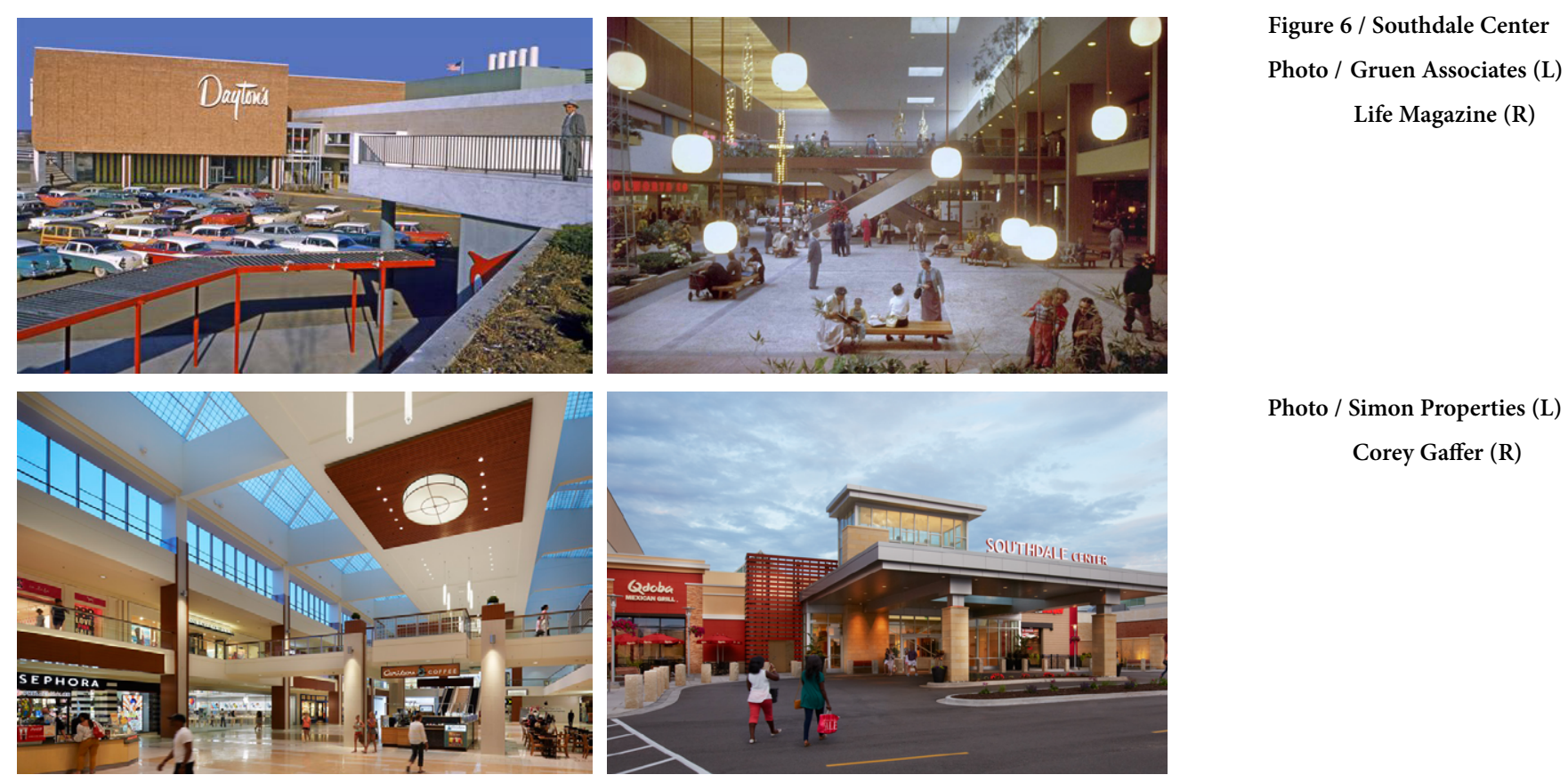

Photo / Simon Properties (L) Corey Gaffer (R)

Stage 5 : 2010 - 2020

Reinvention of the Mall Experience

\section{Economic Trend:}

- $\quad$ Online shopping

- $\quad$ Large scale branded stores

- Collapse of department stores

- Extreme segmentation

- $\quad$ Alternative uses

Design Trend:

- Dynamic environments

- Multi-floor stores

- Brand environments

\section{Sign Trend:}
- Digital signs
- $\quad$ Sign façades
- Double height signs

In the last decade, trends that have been building for twenty years have caused the collapse of a large number of malls. Financial analytics firm Credit Suisse issued a report that predicted that between 225 and 275 enclosed malls would close in the next five years, a number that represents $25 \%$ of all North American malls (Berger, 2018). From 2010 to 2015, 24 malls closed and $20 \%$ of all malls are currently considered troubled. Most of these are class "B" and
" $\mathrm{C}$ " malls that are geared to the middle class while class "A" malls for the wealthy are still successful (Schwartz, 2015). Mall oversaturation combined with a rapid increase in online shopping and a decrease in the desire of younger people to socialize at malls is putting massive pressure on malls to change or close.

The major source of innovation has been class "A" malls primarily focused on the wealthy. These malls provide entertainment options and feature advanced architectural designs. Class "B" and "C" malls are being downsized or adapted into mixed uses including housing and office space (Jones, 2017).

Malls that remain are taking advantage of many of the successful design approaches developed over the last twenty years, including exterior focus, architectural integration and thematic spaces. New technologies and methodologies are highlighting signs as a key strategy for growth . In addition, the return of leading architecture firms to the design of malls has resulted in much greater innovation in both architecture and environmental graphics (Berger, 2018).

If current economic trends hold, the suburban enclosed shopping mall as an egalitarian space for shopping will be a small part of the consumer landscape as luxury entertainment oriented spaces take a larger percentage of future development 


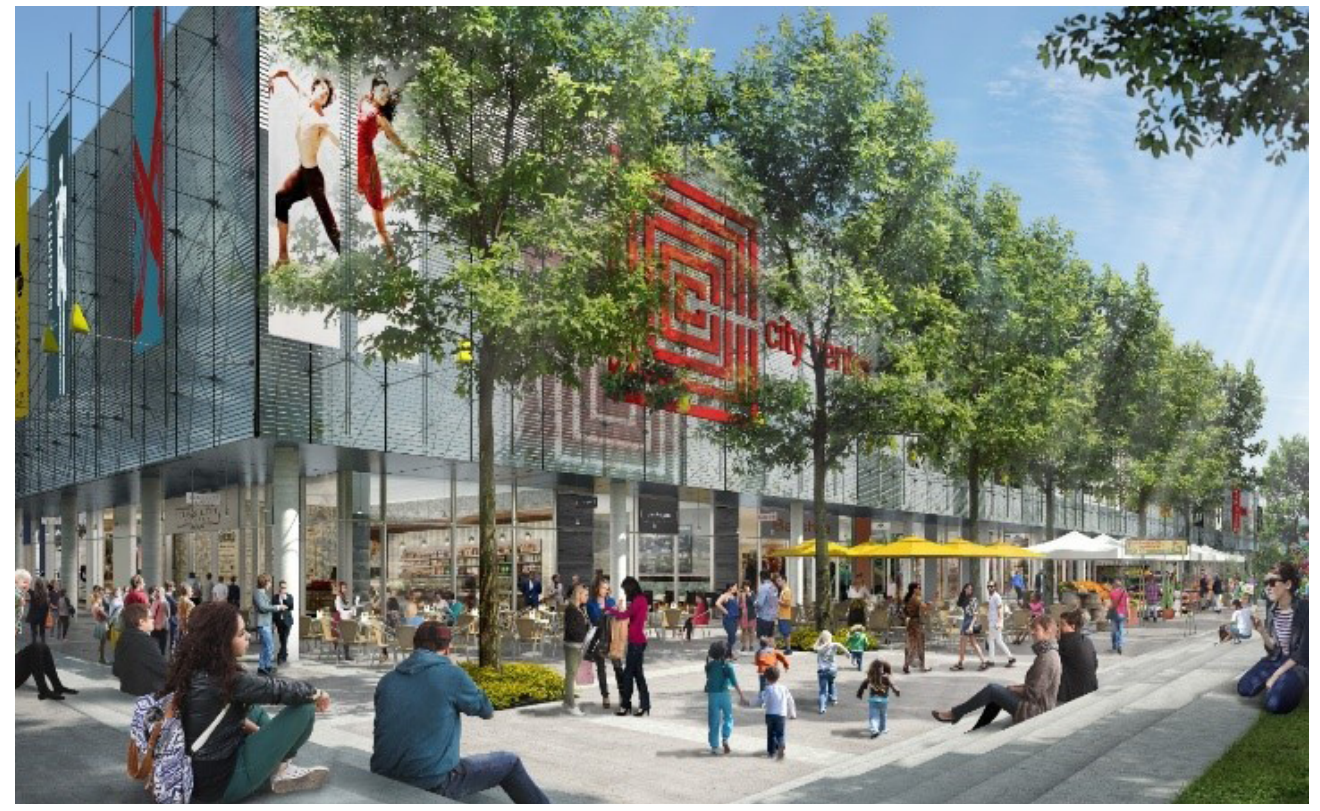

resources. Signs and identity will focus primarily on these new strategies as developers and retailers adopt lessons from each stage of mall development.

\section{LEARNING}

\section{Stage 1 / The Expertise of Architects:}

As they were in the first stage of mall development, famous architects are being asked to take part in the reinvention of class " $\mathrm{A}$ " malls like this new building by Renzo Piano at City Center Bishop Ranch in California (see Figure 7). After seventy years of mall development, the luxury enclosed mall is regarded as an icon to pursue in community development.

\section{Stage 2 / Bigger Stores and More Creative Façades:}

As department stores and small stores close in traditional enclosed malls, "flagship" retailers focused on reinforcing their brand name as much as retail store development are replacing them. These companies, including H\&M, Topshop, and Anthropologie, are mixing with theaters and restaurants to make larger spaces where they have more control, yet still have the amenities of the mall. The result is much greater control by the stores and also more creative and expansive solutions.

The new Yorkdale Mall renovation in Toronto (see Figure 8) was designed by MMC Architecture. In Yorkdale, the new larger stores have double height spaces that allow for much greater architectural and sign innovation on the façades. Unlike previous malls with tight design standards, out-of-the-box thinking is encouraged.

\section{Stage 3 / Digital and Lighting Spectaculars:}

Luxury, themed, and entertainment-oriented malls are still doing well, but they face pressure to stay relevant. The newest approach is the spectacular.
Figure 7 / Artist's rendering of City Center Bishop Ranch

Credit / Bishop Ranch 

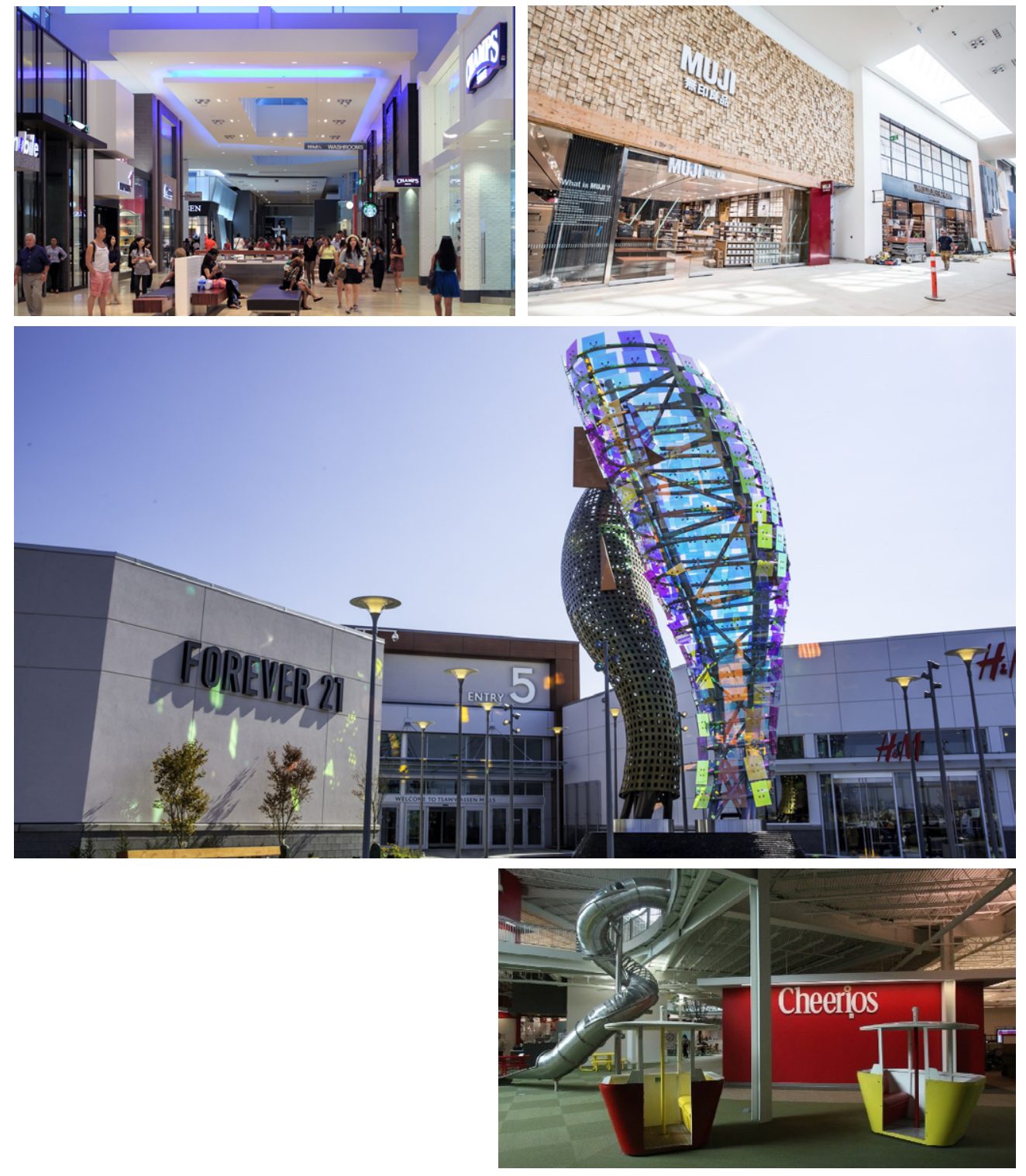

Figure 8 / Yorkdale Mall

Credit / MMC Architects

Figure 9 / Tsawwassen Mills Photo Credit / JPRA Architects

These malls focus on utilizing lighting, sculpture and digital effects to attract mallgoers. For example, Tsawwassen Mills in British Columbia (see Figure 9) developed an incredible combination of illuminated dynamic sculpture and façade display designed by JPRA and fabricated by Knight Signs.

\section{Stage 4 / Conversation:}

Many malls, particularly class " $B$ " and " $C$ " malls, are closing permanently. Some will be demolished or turned into modern archeological ruins, but most will be converted into offices, universities and healthcare campuses. These new spaces will offer a smaller retail component, resulting in a combination of retail and institutional identity. For example, after the Windsor Park Mall in San Antonio failed, it was taken over by Rackspace, a tech firm bringing 3,000 employees to the space. The renovation resulted in a complete changeover of design by Workshop No.5. This design change produced new opportunities for signs and branded space. The new owners, of course, also kept the food court. This combination of retail and institutional 
identity is the future of the middle class enclosed mall.

\section{REFERENCES}

Berger, C.M. (2018, May 23). Commercial signage: The evolution of shopping malls. Sign Media Canada. Retrieved from https://www. signmedia.ca/commercial-signage-the-evolution-of-shopping-malls/

Dugdale, J. (1999) Origins of environmental graphic design in the 20th century. In SEGD Education Foundation (ed.) (Chapter 5.5).

Frieden, B. J., \& Sagalyn, L. B. (1991). Downtown, inc: How America rebuilds cities. MIT press.

Jackson, K. T. (1987). Crabgrass frontier: The suburbanization of the United States. New York: Oxford University Press.

Jones, C. (2017, Aug 21). Malls become models of reinvention to cope with closing stores. USA Today. Retrieved from https://www. usatoday.com/story/money/2017/08/21/malls-try-reinvent-themselves-cope-closing-stores/451814001/

Judd, D. R., \& Fainstein, S. S. (Eds.). (1999). The tourist city. Yale University Press.

Korpacz, P.F. (2017). Regional mall classification methodology 2017. In Korpasz Realty Advisors, Inc. Retrieved from http://www. korpaczra.com/wp-content/uploads/2014/04/Korpacz-Mall-Classification-2017.pdf

Moore, R. (2013, Feb 26). The death of the American mall and the rebirth of public space. The International. Retrieved from http:// www.academia.edu/2650284/The_Death_of_the_American_Mall_and_the_Rebirth_of_Public_Space

Pew Research Center. (2015, Dec 9). The American middle class is losing ground: No longer the majority and falling behind financially. In Social Trends. Retrieved from http://www.pewsocialtrends.org/2015/12/09/the-american-middle-class-is-losing-ground/

Schwartz, N. D. (2015, Jan 3). The economics (and nostalgia) of dead malls. The New York Times. Retrieved from https://www.nytimes. com/2015/01/04/business/the-economics-and-nostalgia-of-dead-malls.html

Underhill, P. (2005). Call of the mall: The geography of shopping by the author of why we buy. Simon and Schuster. 